\title{
Evaluation of HLA-DQ2/DQ8 genotype in patients with celiac disease hospitalised in 2012 at the Department of Paediatrics
}

\author{
Dorota A. Szałowska-Woźniak ${ }^{1}$, Leokadia Bąk-Romaniszynn ${ }^{2,3}$, Agnieszka Cywińska-Bernas ${ }^{1}$, Krzysztof Zeman $^{1}$ \\ ${ }^{1}$ Department of Pediatrics, Preventive Cardiology and Clinical Immunology, Medical University of Lodz, Poland \\ 2Department of Nutrition in Gastrointestinal Disease, Medical University of Lodz, Poland \\ ${ }^{3}$ Department of Pediatrics, Immunology and Nephrology, Polish Mothers Memorial Hospital Research Institute, Lodz, Poland
}

Prz Gastroenterol 2014; 9 (1): 32-37

DOI: $10.5114 / p g .2014 .40848$

Key words: celiac disease, antibodies, genotype, inheritance.

Address for correspondence: Dorota A. Szałowska-Woźniak MD, PhD, Medical University of Lodz, 4 Kościuszki St, $90-419$ Lodz, Poland, phone:+48 6062828 06, e-mail: d.szalowska@interia.pl

\begin{abstract}
Introduction: Celiac disease (CD) is a permanent intolerance to gluten that occurs in genetically predisposed individuals and leads to small intestinal mucosa damage. According to ESPGHAN guidelines from 2012, CD can be diagnosed in a patient with characteristic clinical symptoms, in whom, anti-tissue transglutaminase antibodies ( $>10$ times the upper limit) are found, endomysial antibodies (EMA) is confirmed and a positive genetic test is obtained. In these conditions no small-bowel biopsies are required.

Aim: Evaluation of the presence of HLA-DQ2 and HLA-DQ8 haplotypes in children with previously diagnosed CD, hospitalised in 2012 at the Department of Paediatrics and Immunology and/or the Gastroenterological Outpatient Clinic, and their relatives.

Material and methods: Blood samples of 22 subjects, including 9 children with CD diagnosed on the basis of clinical symptoms, serological investigations and small-intestine biopsy, 7 diagnosed on the basis of clinical symptoms and serological investigations, 2 with the suspicion of CD on the basis of clinical symptoms and 4 relatives of a child with CD. Methods: HLA-DQ2/ DQ8 test, automatic evaluation by EUROArrayScan.

Results: The presence of HLA-DQ2 and/or HLA-DQ8 genotype was confirmed in 16 children with CD diagnosed on the basis of clinical symptoms and serological tests with/without intestinal biopsy, in 2 with the suspicion of CD and in 1 relative of a celiac child.

Conclusions: The evaluation of HLA-DQ2/DQ8 haplotype confirms the genetic predisposition to CD in subjects with the disease diagnosed previously on the basis of clinical symptoms, serological tests or intestinal biopsy. Genetic testing is particularly indicated for the diagnosis of CD in infants consuming gluten for a short time and in small amounts.
\end{abstract}

\section{Introduction}

Celiac disease $(C D)$ is a genetically conditioned abnormal response to gluten, which in the course of autoimmune processes leads to small intestinal mucosa damage. Based on screening for CD performed in Europe and in the USA, its prevalence varies from $1: 100$ to $1: 300$ of the population, and for its symptomatic form - 1 : 3345 individuals [1]. However, despite the availability of serological and genetic testing and intestinal biopsy, the ratio of individuals with diagnosed CD and non-diagnosed cases is $1: 7$, which is associated, among others, with different levels of physicians' knowledge about this disease [1]. The prevalence of CD in children and adolescents aged 2.5 to 15 years is $3-13 / 1000$ of tested children, in Europe from $1: 80$ to $1: 300$ [2-4]. The results of the epidemiological investigations carried out in Poland in the years 2007-2009 indicated similar to the above for the incidence of celiac disease. It has been estimated that in Poland the number of children and adolescents up to 19 years of age suffering from CD was from 25,000 to as many as 75,000 individuals, and probably a significant amount remain undiagnosed [5]. Gluten is a fraction of proteins present in grains of wheat (gliadin), rye (secalin) and barley (hordein). Exposure to gluten, in genetically predisposed individuals, leads tothe development of immune reactions asso- 
ciated with the activation of TCD4, CD8 lymphocytes, production of pro-inflammatory cytokines, excessive proliferation of intraepithelial lymphocytes, migration of macrophages to the intestinal wall and finally to intestinal mucosa damage (flattening of villi to total villous atrophy, crypt hypertrophy and the increase of intraepithelial lymphocytes) [6]. The severity of changes developing in small-bowel mucosa is classified by Marsh scale (1992) and modified by Oberhuber et al. [7-13]. In the course of celiac disease, besides the activation of $T$ lymphocytes, there is induction of $\beta$ lymphocytes, which produces specific antibodies - the markers for the disease. They include: tissue transglutaminase 2 (tTG2), endomysial antibodies (EMA) and the deamidated form of gliadin peptides (DPG). The determination of their concentration is routinely performed in IgA class, but in patients with serum immunoglobulin A deficiency (IgA $<0.2 \mathrm{~g} / \mathrm{l})$ in IgG class $[1,14,15]$. HLA haplotype testing is of great value in the diagnosis of $C D$, and it also allows determination of the risk for this disease occurrence. In the ESPGHAN (European Society for Paediatric Gastroenterology) guidelines from 2012, genetic testing has been included in the diagnostic management of celiac disease. It has been acknowledged that in the case of clinical symptoms of CD occurring in a patient together with the presence of anti-tissue transglutaminase antibodies (> 10 times the upper limit of normal), the presence of anti-endomysial antibodies and the presence of class II HLA-DQ2 and/or DQ8 haplotype, CD can be diagnosed without the necessity of small-bowel biopsy [16]. HLA-DQ2 is present in $90-95 \%$ of CD patients, whereas HLA-DQ8 is present in about 5-15\% [17]. HLA-DQ2 and/or DQ8 allele is not found in only $1 \%$ of celiac patients. The presence of HLA-DQ2 and/or DQ8 is indispensable but insufficient for the development of the disease; HLA-DQ2 genotype is also observed in $25-30 \%$ and HLA-DQ8 in $5-10 \%$ of the general population [1]. Additionally, other genes not associated with MCH class II family (non-HLA genes), e.g. CTLA4 gene polymorphism (gene located on chromosome 2q33), PTP N22 (protein tyrosine-phosphatase nonreceptor 22), are responsible for susceptibility to CD [18-20]. HLA-DQ2 and HLA-DQ8 genes are located on chromosome 6p21. HLA-DQ2 consists of HLA-DQA $1^{\star} 05$ (subunit $\alpha$ ) allele and HLA-DQB1*02 (subunit $\beta$ ) allele, and HLA-DQ8 genotype consists of HLA-DQA $1^{\star} 0301$ (subunit $\alpha$ ) allele and HLA-DQB1*0302 (subunit $\beta$ ) allele [21].

\section{Aim}

The aim of the study was to evaluate the presence of HLA-DQ2 and HLA-DQ8 haplotypes, predisposing to CD development in children with previously diagnosed celiac disease, hospitalised in 2012 at the Department of Paediatrics and Immunology and/or the patients of the Gastroenterological Outpatient Clinic and their relatives.

\section{Material and methods}

The study included 22 subjects ( 13 women, 9 men): 20 children (aged from 11 months to 17.3 years) and 2 adults (father - aged 46.2 years and mother - aged 44 years, of a boy with $C D$ ), the mean age was in the whole group was 8.3 years. The investigated group comprised 9 children with CD diagnosed on the basis of characteristic clinical symptoms, serological investigations and positive result of small-bowel biopsy, 7 children with the disease diagnosed on the basis of clinical symptoms, serological investigations, without small-bowel biopsy, 2 children (11 and 14 months old) with suspected $\mathrm{CD}$ on the basis of clinical symptoms, and 4 first-degree relatives of a celiac child (mother, father, brother and sister) (Table I). In the group of 18 children 12 (67\%) had coexisting diseases: 6 were treated due to allergy, 2 due to Duhring's disease, 2 with bronchial asthma, 1 with diagnosed Crohn's disease and hypothyroidism, 1 congenital optic nerve anomaly and reactive arthritis, 1 nephrotic syndrome and 1 girl was diagnosed with autoimmune hepatitis.

Whole venous blood (2-3 ml) was used. The "EUROArrayScan" test was used for HLA-DQ2DQ8 determination. The tests were performed in a laboratory experienced in performing such determinations. All patients and their parents were informed about the purpose of the determination and gave their written consent to perform their and their child's genetic testing.

\section{Results}

In 19 (86.3\%) of 22 individuals HLA-DQ2 or HLADQ8 was detected (12 in females and 7 in males). Genetic predisposition to CD was confirmed in all 16 patients with CD diagnosed on the basis of clinical symptoms and positive results of serological investigations with or without small-bowel biopsy, in 2 patients with suspected disease on the basis of clinical symptoms (11- and 14-month-old children receiving gluten for a short time) and in 1 adult (mother of celiac boy), i.e. the presence of HLA-DQ2 and/or HLA-DQ8 genotype (Figures 1, 2). Among individuals with positive haplotype associated with celiac disease, 13 (68\%) had HLADQ2, 4 (21\%) had HLA-DQ8, and 2 (11\%) had HLA-DQ2 and HLA-DQ8 (Figure 3). In 3 individuals, first-degree relatives (father, aged 46 years, brother aged 12 years and 7 months, sister aged 19 months) of a boy with CD, no HLA-DQ2/DQ8 alleles were found. The boy's brother and sister remained on a gluten-free diet due to suspicion of $C D$ despite negative results of serological in- 
Table I. Characteristics of the investigated group

\begin{tabular}{|c|c|c|c|c|c|c|c|}
\hline \multicolumn{8}{|c|}{ Children } \\
\hline $\begin{array}{l}\text { Patient's } \\
\text { no: }\end{array}$ & Gender & Age & $\begin{array}{c}\text { Clinical } \\
\text { symptoms of } \\
\text { celiac disease }\end{array}$ & Biopsy & $\begin{array}{l}\text { Biopsy } \\
\text { result }\end{array}$ & Coexisting diseases & Serology results \\
\hline 1 & M & $\begin{array}{l}10 \text { years } \\
8 \text { months }\end{array}$ & Yes & No & - & $\begin{array}{l}\text { Congenital optic nerve anomaly, } \\
\text { reactive arthritis }\end{array}$ & $\begin{array}{l}\text { tTGA positive, } \\
\text { AGA negative }\end{array}$ \\
\hline 2 & $\mathrm{~F}$ & 2 years & Yes & No & - & & $\begin{array}{l}\text { tTGA positive, } \\
\text { EMA positive, } \\
\text { AGA positive }\end{array}$ \\
\hline 3 & $\mathrm{~F}$ & $\begin{array}{l}8 \text { years } \\
1 \text { month }\end{array}$ & Yes & Yes & III C & Inhaled allergy & EMA positive \\
\hline 4 & M & $\begin{array}{l}4 \text { years } \\
4 \text { months }\end{array}$ & Yes & No & - & $\begin{array}{c}\text { Food and inhaled allergy, } \\
\text { bronchial asthma, } \\
\text { atopic dermatitis }\end{array}$ & $\begin{array}{l}\text { tTGA positive, } \\
\text { EMA positive }\end{array}$ \\
\hline 5 & M & $\begin{array}{l}16 \text { years } \\
3 \text { months }\end{array}$ & Yes & Yes & IIla & Crohn disease, hypothyroidism & $\begin{array}{l}\text { tTGA negative, } \\
\text { AGA positive }\end{array}$ \\
\hline 6 & M & $\begin{array}{l}11 \text { years } \\
3 \text { months }\end{array}$ & Yes & Yes & $\| I I b$ & Bronchial asthma, polyvalent allergy & $\begin{array}{l}\text { tTGA positive, } \\
\text { EMA positive }\end{array}$ \\
\hline 7 & M & $\begin{array}{l}12 \text { years } \\
8 \text { months }\end{array}$ & Yes & Yes & IIIC & Nephrotic syndrome, polyvalent allergy & $\begin{array}{l}\text { tTGA positive, } \\
\text { EMA positive }\end{array}$ \\
\hline 8 & $\mathrm{~F}$ & $\begin{array}{l}12 \text { years } \\
1 \text { month }\end{array}$ & Yes & Yes & IIIC & IgA nephropathy & $\begin{array}{l}\text { tTGA positive, } \\
\text { EMA positive }\end{array}$ \\
\hline 9 & M & $\begin{array}{l}3 \text { years } \\
11 \text { months }\end{array}$ & Yes & No & - & & $\begin{array}{l}\text { tTGA positive, } \\
\text { AGA positive }\end{array}$ \\
\hline 10 & M & $\begin{array}{l}1 \text { year } \\
2 \text { months }\end{array}$ & Yes & No & - & & $\begin{array}{l}\text { tTGA negative, } \\
\text { AGA negative }\end{array}$ \\
\hline 11 & $\mathrm{~F}$ & $\begin{array}{l}15 \text { years } \\
4 \text { months }\end{array}$ & Yes & Yes & IIIC & & $\begin{array}{l}\text { tTGA positive, } \\
\text { AGA positive }\end{array}$ \\
\hline 12 & $\mathrm{~F}$ & $\begin{array}{l}12 \text { years } \\
3 \text { months }\end{array}$ & Yes & Yes & $\| I I b$ & Duhring's disease & $\begin{array}{l}\text { No before-diet } \\
\text { results }\end{array}$ \\
\hline 13 & $\mathrm{~F}$ & $\begin{array}{l}5 \text { years } \\
1 \text { month }\end{array}$ & Yes & Yes & IIIC & & $\begin{array}{l}\text { tTGA positive, } \\
\text { EMA positive }\end{array}$ \\
\hline 14 & $\mathrm{~F}$ & 11 months & Yes & No & - & & tTGA negative \\
\hline 15 & $\mathrm{~F}$ & $\begin{array}{c}1 \text { year } \\
2 \text { months }\end{array}$ & Yes & No & - & Duhring's disease & AGA positive \\
\hline 16 & $\mathrm{~F}$ & 12 years & Yes & Yes & IIIC & & tTGA positive \\
\hline 17 & $\mathrm{~F}$ & $\begin{array}{l}17 \text { years } \\
3 \text { months }\end{array}$ & Yes & No & - & Autoimmune hepatitis & $\begin{array}{l}\text { tTGA positive, } \\
\text { EMA positive }\end{array}$ \\
\hline 18 & $\mathrm{~F}$ & $\begin{array}{l}6 \text { years } \\
5 \text { months }\end{array}$ & Yes & No & - & & tTGA positive \\
\hline \multicolumn{8}{|c|}{ Celiac child first-degree relatives } \\
\hline \multicolumn{8}{|c|}{ Siblings } \\
\hline 19 & $\mathrm{~F}$ & $\begin{array}{l}1 \text { year } \\
9 \text { months }\end{array}$ & No & No & - & Food allergy & $\begin{array}{l}\text { tTGAnegative, } \\
\text { EMA negative }\end{array}$ \\
\hline 20 & M & $\begin{array}{l}12 \text { years } \\
7 \text { months }\end{array}$ & Yes & No & - & Food allergy & $\begin{array}{l}\text { tTGA negative, } \\
\text { AGA negative }\end{array}$ \\
\hline \multicolumn{8}{|c|}{ Parents } \\
\hline 21 & M & $\begin{array}{l}46 \text { years } \\
2 \text { months }\end{array}$ & Yes & No & - & & $\begin{array}{l}\text { On gluten-free } \\
\text { diet: } \\
\text { tTGA negative, } \\
\text { AGA negative }\end{array}$ \\
\hline 22 & $\mathrm{~F}$ & 44 years & No & No & - & & tTGA negative \\
\hline
\end{tabular}




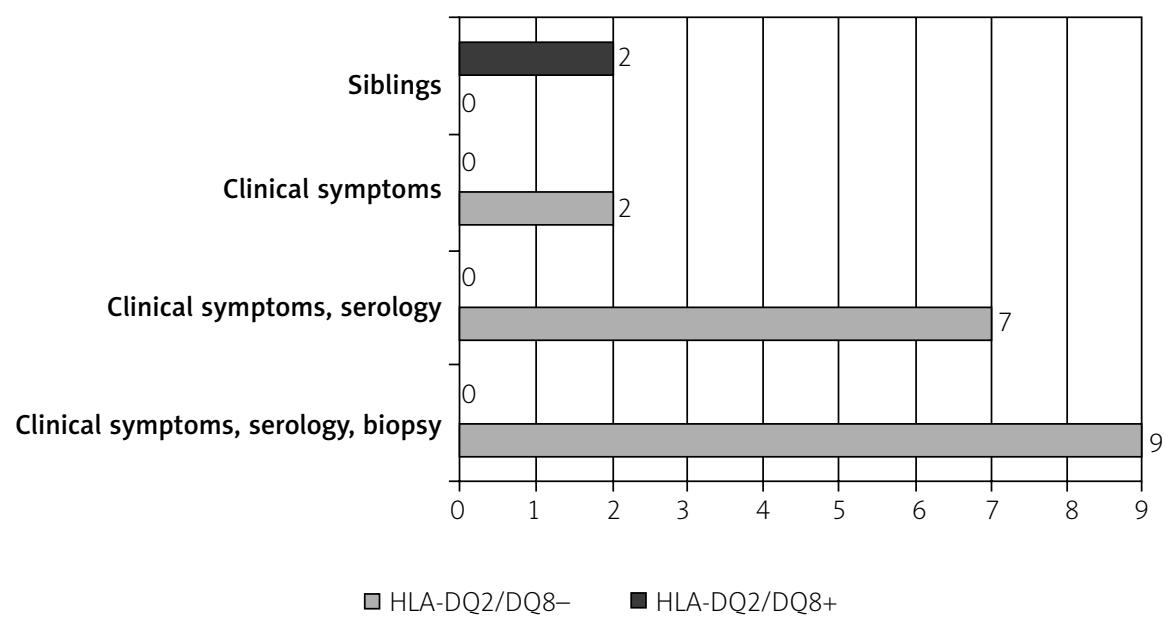

Figure 1. Evaluation of HLA-DQ2/DQ8 genotype in the examined children $(n=20)$

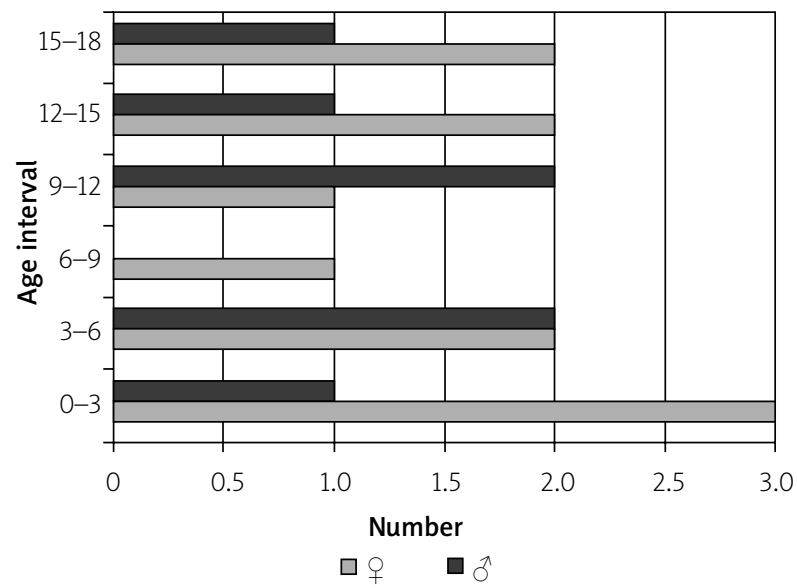

Figure 2. Gender distribution in the population of subjects up to 18 years old of the life with positive results of testing $(n=18)$

vestigations but with traits of food allergy and irregular bowel movements. The father of the family eliminated gluten from his diet due to recurrent abdominal pain. In the mother, treated as healthy subject, after a positive result of genetic testing for celiac disease, a silent form of the disease was diagnosed.

\section{Discussion}

The genetic susceptibility to CD was confirmed in the tests of all children with intestinal mucosa atrophy (Marsh III), in serologically positive children, and even in two infants only with clinical symptoms of the disease. In the Polish project of genetic testing of celiac disease, performed in the years 2007-2009, including 922 subjects: 594 with diagnosed celiac disease, 131 with suspicion for CD and 141 from celiac families, 79\% had a positive result of SNP genotyping (genetic varia-

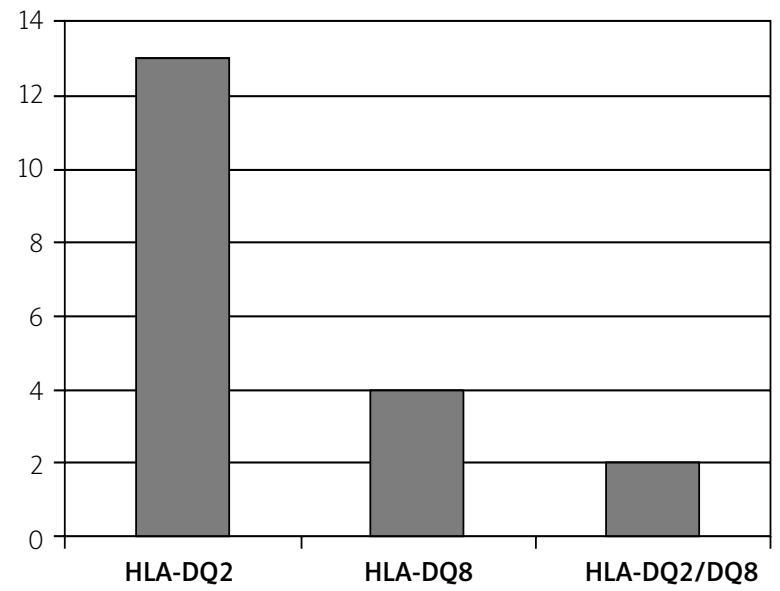

Figure 3. Distribution of HLA-DQ2/DQ8 haplotypes of subjects with positive result of genetic testing $(n=19)$

tions of single nucleotide polymorphism) for DQ2 and/or DQ8. Positive results of genotyping were demonstrated in $97 \%$ of patients with diagnosed CD and in $47 \%$ of individuals suspected for CD [22]. In the study of Kipatany et al. in 2006 from the University in Debreczyn, similarly as in our study, all 40 investigated subjects, in whom the presence of anti-tissue transglutaminase antibodies and EMA was confirmed, had HLA-DQ2 or DQ8 allele [10]. The evaluation of the genotype for the presence of HLA-DQ2/DQ8, as we became convinced in our study, is a test allowing early recognition of $C D$ in children who receive gluten for a short time and/or in a small amount. In the group investigated by us, a positive result of HLA-DQ2/DQ8 was obtained in a 14-month-old boy and positive HLA-DQ8 in an 18-month-old girl with insufficient weight gain and growth despite a negative result of serum tissue trans- 
glutaminase. In ESPGHAN guidelines low diagnostic reliability has been emphasized for serological investigations for $C D$ in children $<2$ years of age remaining on a gluten-free diet or consuming gluten for a short time and in a small amount, with accompanying diseases, in the evaluation of familial predisposition to the disease and in subjects treated with immunosuppressive agents [16]. It has been emphasised that a negative result of HLA-DQ2/DQ8 test excludes CD in $99 \%$ and a positive result points to the disease or to a predisposition to it $[1,16]$. The performance of genetic testing is indicated to recognise or exclude CD in patients with ambiguous or contradictory results of serological and histopathological investigations and also in individuals remaining on a gluten-free diet (when the results of histopathological and serological tests can be false negative). The evaluation of HLA-DQ2/DQ8 is also indicated in the socalled risk groups, i.e. first-degree relatives of celiac patients, patients with type I diabetes mellitus and pathologies coexisting with CD (Down's syndrome, Turner's syndrome, Duhring's disease and others). Confirmation of a predisposition to celiac disease by genetic testing is, for the patients, an additional confirmation of the validity of the application of a restrictive gluten-free diet. In our studies the negative result of genetic testing in 3 subjects allowed the exclusion of CD and enabled the decision to be made for gradual introduction of gluten into the diet, which allows the development of sensitivity in an allergy. In the group investigated by us, in $67 \%$ of children with celiac disease, chronic diseases were present including those of immunological background. This is in compliance with the observations of other authors; CD often coexists with other diseases, most frequently with type I diabetes, autoimmune thyroiditis, IgA nephropathy, Down's syndrome, Turner's syndrome, Williams syndrome, isolated IgA deficiency and nonspecific intestinal diseases [23].

\section{Conclusions}

The evaluation of HLA-DQ2/DQ8 haplotype confirms the genetic predisposition to $C D$ in individuals with previously recognised disease on the basis of clinical symptoms, serological investigations or intestinal biopsy. A positive result of the genetic test confirming a predisposition to $C D$ in a small child receiving gluten for a short time (or with clinical symptoms of the disease) is an indication for further medical supervision and periodic serological testing.

\section{References}

1. Hill ID, Dirks MH, Liptatk GS, et al. Guideline for the diagnosis and treatment of celiac disease in children: recommendations of the North American Society for Pediatric Gastroenterology,
Hepatology and Nutrition. J Pediatr Gastroenterol Nutr 2005; 40: 1-19.

2. Gujral N, Frejman HJ, Thomson A. Celiac disease: prevalence, diagnosis, pathogenesis and treatment. World J Gastroenterol 2012; 8: 6036-59.

3. Iwańczak F, Iwańczak B. New guidelines for diagnosis and treatment of coeliac disease in children and adolescens [Polish]. Prz Gastroenterol 2012; 7: 185-91.

4. Tommasini A, Not T, Kiren V, et al. Mass screening for coeliac disease using antihuman transglutaminase antibody assay. Arch Dis Child 2004; 89: 512-15.

5. Szaflarska-Popławska A, Karczewska K, Żabka A, et al. Occurence of celiac disease in Poland - multicenter study [Polish]. Ped Współcz Gastroenterol Hepatol Żyw Dz 2009; 11: 111-6.

6. Szczeblowska D, Hebzda A, Serwin D, et al. Celiac disease - not just the domain of pediatrics [Polish]. Pediatr Med Rodz 2010; 6: 22-6.

7. Marsh MN. Grains of truth: evolutionary changes in small intestinal mucosa in response to environmental antigen challenge. Gut 1990; 31: 111-4.

8. Oberhuber G, Granditsch G, Vogelsang H. The histopathology of coeliac disease: time for a standardized report scheme for pathologistis. Eur J Gastroenterol Hepatol 1999; 11: 1185-94.

9. Weir DC, Glickman JN, Roiff T, et al. Variability of histopathological changes and childhood celiac disease. Am J Gastroenterol 2010; 105: 207-12.

10. Kipatany A, Toth L, Lumpek J. Diagnostic significance of HLADQ typing in patients with previous celiac disease diagnosis based on histology alone. Aliment Pharmacol Ther 2006; 24: 1395-402.

11. Barton SH, Murray JA. Celiac disease and autoimmunity in the gut and elsewhere. Gastroenterol Clin North Am 2008; 37 : 411-28.

12. Kagnoff MF. Celiac disease: pathogenesis of a model immunogenetic disease. J Clin Invest 2007; 26: 157-8.

13. Prasad KK, Thapa BR, Nain CK. The frequency of histologic session variability of the duodenal mucosa in children with celiac disease. World J Pediatr 2010; 6: 60-4.

14. Ravelli A, Villanacci V, Manfredini C. How patchy is villous atrophy? Distribution pattern of histological lesions in the duodenum of children with celiac disease. Am J Gastroenterol 2010; 105: 2103-10.

15. Szaflarska-Popławska A, Parsęcka M. Difficulties in the diagnosis of coeliac disease in 17-year-old girl with changes limited to the small intestine not confirmed with traditional gastroduodenoscopy - a case report [Polish]. Gastroneterol Pol 2012; 19: 129-32.

16. Husby S, Koletzko S, Korponay-Szabo IR, et al. European Society for Pediatric Gastroenterology, Hepatology, and Nutrition Guidelines for the diagnosis of coeliac disease. J Pediatr Gastroenterol Nutr 2012; 54: 136-60.

17. Schuman D. Current concepts of celiac disease pathogenesis. Gastroenterology 2000; 119: 234-42.

18. Simone R, Brizzolara R, Chiappori A, et al. A functional soluble form of CTLA-4 is present in the serum of celiac patients and correlates with mucosal injury. Int Immunol 2009; 21: 1037-45.

19. Wolters VM, Wijmenga C. Genetic background of celiac disease and its clinical implications. Am J Gastroenterol 2008; 103: $190-5$ 
20. Romanos J, Barisani D, Trynka G, et al. Six new coeliac disease loci replicated in an Italian population confirm association with celiac disease. J Med Genet 2009; 46: 60-3.

21. Jenkins HR, Murch SH, Beattie RM. Diagnosing coeliac disease. Arch Dis Child 2012; 97: 393-4.

22. Kaniewska M, Rydzewska G. Celiac disease in adults-pathogenesis, clinical manifestations, coexistens with inflammatory bowel disease and other disease with immunological background [Polish]. Prz Gastroenterol 2009; 4: 173-7.

23. Rybak A, Domagała Z, Szaflarska-Popławska A, et al. Summary of the project nationwide genetic testing in celiac disease [Polish]. Ped Współcz Gastroenterol Hepatol Żyw Dz 2009; 11: 126.

Received: $\quad 15.02 .2013$

Accepted: 15.09.2013 